\title{
REVIEW
}

\section{Androgen excess in breast cancer development: implications for prevention and treatment}

\author{
Giorgio Secreto1, Alessandro Girombelli2 and Vittorio Krogh1 \\ ${ }^{1}$ Epidemiology and Prevention Unit, Fondazione IRCCS - Istituto Nazionale dei Tumori, Milano, Italy \\ ${ }^{2}$ Anesthesia and Critical Care Medicine, ASST - Grande Ospedale Metropolitano Niguarda, Milano, Italy
}

Correspondence should be addressed to G Secreto: secretog44@gmail.com

\begin{abstract}
The aim of this review is to highlight the pivotal role of androgen excess in the development of breast cancer. Available evidence suggests that testosterone controls breast epithelial growth through a balanced interaction between its two active metabolites: cell proliferation is promoted by estradiol while it is inhibited by dihydrotestosterone. A chronic overproduction of testosterone (e.g. ovarian stromal hyperplasia) results in an increased estrogen production and cell proliferation that are no longer counterbalanced by dihydrotestosterone. This shift in the androgen/ estrogen balance partakes in the genesis of ER-positive tumors. The mammary gland is a modified apocrine gland, a fact rarely considered in breast carcinogenesis. When stimulated by androgens, apocrine cells synthesize epidermal growth factor (EGF) that triggers the ErbB family receptors. These include the EGF receptor and the human epithelial growth factor 2, both well known for stimulating cellular proliferation. As a result, an excessive production of androgens is capable of directly stimulating growth in apocrine and apocrine-like tumors, a subset of ER-negative/AR-positive tumors. The key role of androgen excess in the genesis of different subtypes of breast cancer has significant clinical implications for both treatment and prevention. Our belief stems from a thorough analysis of the literature, where an abundance of evidence is present to justify a clinical trial that would investigate the effectiveness of treating the underlying excessive androgen production.
\end{abstract}

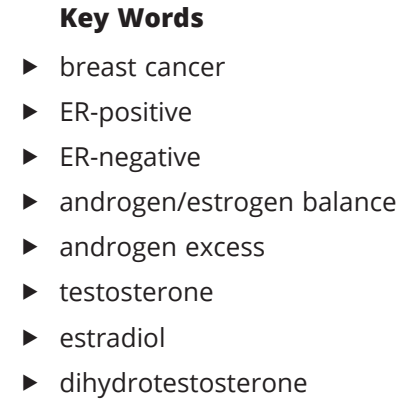

Endocrine-Related Cancer (2019) 26, R81-R94

\section{Introduction}

It is a well-known fact that androgens act mostly as growth inhibitors on breast cancer.

In apparent contrast with this common belief, the androgen-excess theory of breast cancer (Secreto $2012 a, b)$ postulates that androgen excess is the pivotal endocrine derangement in women with breast cancer. In this review, we propose a novel approach to breast cancer development by emphasizing the central role of excessive androgen production in this process.
We will describe the mechanisms of tumor promotion by androgens and we will discuss the protective role of androgens in breast cancer, providing the available evidence from the literature to support our claim. Lastly, we will briefly reiterate the clinical implications of androgen excess discussed in previous papers on the prevention (Secreto et al. 2016) and treatment (Secreto et al. 2017) of estrogen receptor (ER)-positive breast cancer. 


\section{Androgen excess in the development of ER-positive breast cancer}

Studies on normal breast development have shown how androgens display growth inhibitory properties in puberty and anti-proliferative and anti-estrogenic properties during adulthood (Casey \& Wilson 1984, Liao \& Dickson 2002, Peters et al. 2011). In contrast, estrogens and progesterone have been found to promote breast development in puberty and induce profound changes in the gland's structure. With each menstrual cycle the mammary gland undergoes proliferation, differentiation and regression, a process that repeats itself from puberty to menopause. After menopause, regressive phenomena prevail, resulting in progressive replacement of the glandular structure with adipose tissue. A more refined growth control mechanism is enforced by the local production of polypeptide growth factors that modulate steroid activity through autocrine and paracrine mechanisms (Borellini \& Oka 1989, Cunha 1994, Reid et al. 1996). The interactions between mesenchymal and epithelial tissue are mediated by a paracrine signaling network comprising growth factors, cytokines and extracellular matrix molecules, all of which are part of a unique anatomo-functional entity (Imagawa et al. 2002, Shekhar et al. 2003, Fleming et al. 2010).

\section{The androgen/estrogen balance in the hormonal control network of epithelial proliferation}

Under physiological conditions, estrogens stimulate cellular proliferation while androgens inhibit it. These two hormones can be regarded as an endocrine control mechanism just like the insulin/glucagon pair in controlling glycemia or the parathyroid hormone/calcitonin pair in regulating calcemia. Unlike the hormonal pairs mentioned above, androgens are the obligated precursors for estrogen synthesis and thus can either directly inhibit breast epithelium growth or stimulate it via conversion into estrogens. The dynamic equilibrium between androgens and estrogens provides proper control of mammary epithelial growth in response to the different needs of puberty, menstrual cycles and menopause. In pathological or para-physiological states (i.e. polycystic ovarian disease, ovarian stromal hyperplasia, ovarian hyperthecosis, congenital adrenal hyperplasia), excessive androgen production results in increased estrogen synthesis, which, in turn, overstimulates cell proliferation. At the same time, those same elevated androgen levels attempt to counteract the stimulatory influence of increased estrogen activity. At first, the androgen/estrogen balance is maintained, albeit at a higher than normal level. Nonetheless, the estrogens' pro-proliferative effect will ultimately prevail if the source of excessive androgen production is not removed and the pathological spiral (high androgens $\rightarrow$ high estrogens $\rightarrow$ high proliferation) is not broken (Fig. 1). This chain of events emphasizes the central role of androgen excess in the development of diseases, such as breast cancer, often regarded as estrogen dependent. We suggest that the losing struggle of androgens to maintain the androgen/estrogen balance may explain why the development of breast cancer occurs in stages: simple epithelial hyperplasia, atypical hyperplasia, carcinoma in situ, infiltrating carcinoma.

A recent study in women with benign breast disease who underwent serial biopsies has shown the progression of epithelial proliferation from the first to the subsequent biopsies (i.e. from non-proliferative to proliferative or from simple proliferative to atypical histological subtypes) to be associated with an increased breast cancer risk when compared to no change. However, the risk decreased when the initial histological diagnosis of a proliferative subtype regressed to non-proliferative in later biopsies (Visscher et al. 2017). These findings support the hypothesis that breast cancer develops in stages. We believe that the androgen/estrogen imbalance might either promote the progression through these stages or halt the process, depending on which hormone prevails.

\section{The protective role of androgens in breast cancer}

Clinical evidence shows a $20-30 \%$ remission rate from metastases in patients treated with high-dose androgens (Goldenberg 1964, Talley et al. 1973). A similar percentage was observed with high-dose estrogens (Carter et al. 1977, Ingle 2002, Iwase et al. 2013) and high-dose progestins (Hortobagyi et al. 1985). These results suggest that the use of a high-dose sex hormone (i.e. androgens, estrogens or progestins) may halt the progression of metastatic breast cancer by blocking the hypothalamic-pituitary-gonadal axis. However, these data alone do not support a specific protective role of androgens since all sex hormones, when administered at high doses, can have the same effect.

Further evidence on the beneficial role of androgens can be found in the link between androgen receptor (AR) positivity and improved outcomes in ER-positive tumors, as shown in several clinical studies (Niemeier et al. 2010, Hu et al. 2011, Vera-Badillo et al. 2014, Elebro et al. 2015). We believe that the androgens' favorable effect is consistent with our androgen/estrogen balance theory. These findings reveal but a fraction of the intricate mechanism 


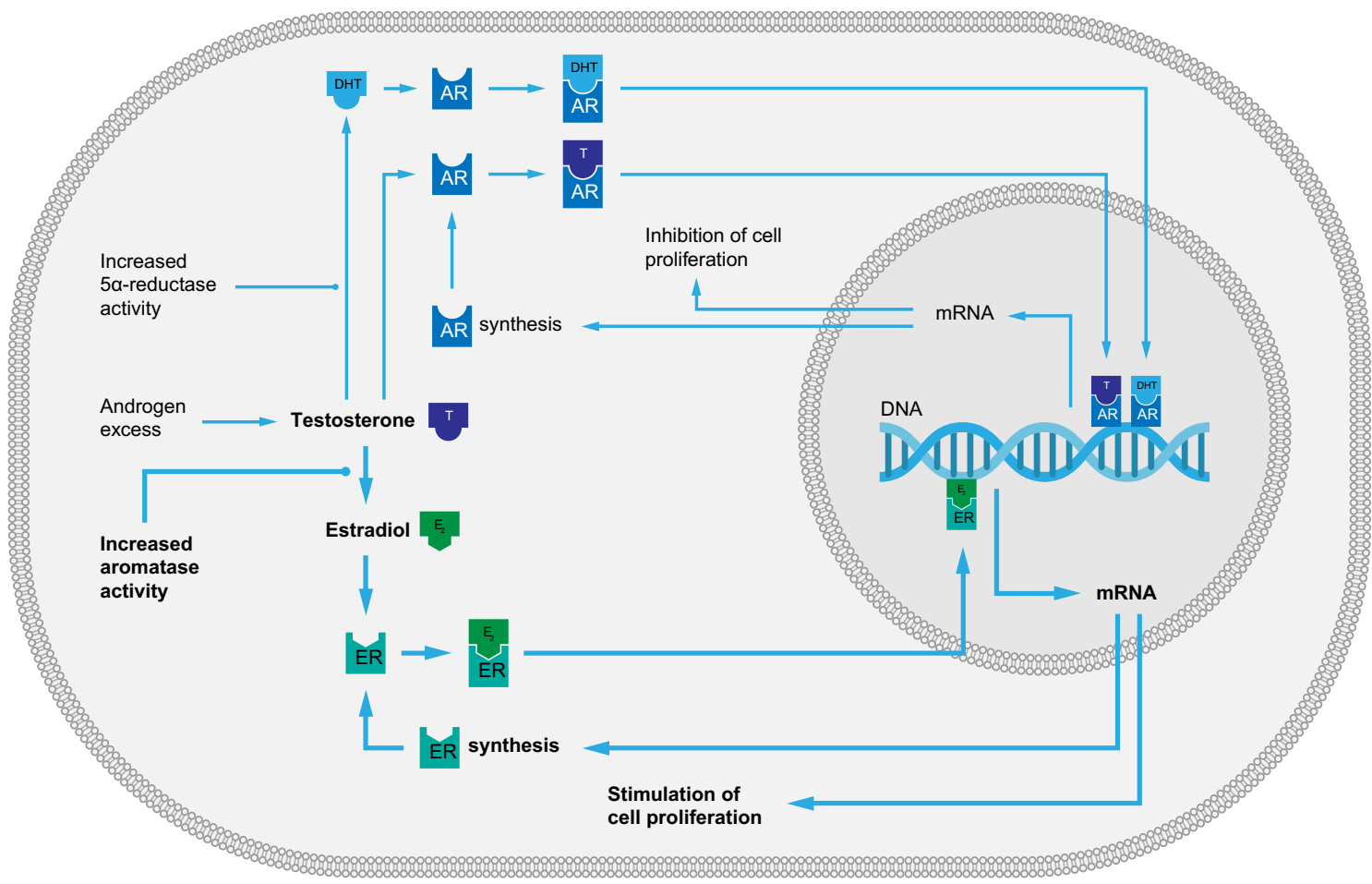

\section{Figure 1}

Simplified illustration of the androgen/estrogen imbalance in the development of estrogen receptor (ER)-positive breast cancer. The figure shows the cascade of events inside cancer cells that starts with the excess testosterone being converted into its two biologically active metabolites: estradiol and dihydrotestosterone (DHT). Testosterone represents androgen excess. Persistently elevated testosterone levels, in conjunction with increased aromatase activity, fuel the continuous synthesis of high estradiol levels resulting, on the one hand, in constant cell proliferation and, on the other, in the upregulation of ER synthesis. This creates a vicious circle resulting in the continuous binding of estradiol to its receptor. The estrogen-induced proliferation cannot be adequately controlled by the same high testosterone levels that first triggered the process. At the same time, high $5 \alpha-$ reductase activity increases the conversion of testosterone into its stronger, non-aromatizable metabolite, DHT, exerting an anti-estrogenic and a growth inhibitory effect. DHT hinders epithelial cell proliferation for some time but is unable to revert the proliferative process back to normal unless the source of the androgen excess is removed, effectively halting the excessive estradiol production.

that is cancer growth control, where androgens exert both inhibitory and stimulatory influences.

In a number of preclinical studies on animals, androgens were shown to inhibit cancer growth and favor the regression of already established tumors (Liao \& Dickson 2002, Choi et al. 2014). Yet, in other papers, androgens were shown to enhance tumor growth (Liao \& Dickson 2002, Choi et al. 2014) and possibly synergize with estrogens in breast carcinogenesis (Liao \& Dickson 2002). The discrepancy between these studies might be due to differences in their design, in the use of aromatizable or non-aromatizable androgens and in mechanisms of tumor induction (Choi et al. 2014). Similar apparently inconclusive results were obtained in cellculture studies, where the findings might largely depend on cell type and experimental conditions. Nonetheless, we suggest administering non-aromatizable androgens (dihydrotestosterone (DHT), mibolerone) to already established ER-positive breast cancer cells may exert only an anti-proliferative effect. However, it should be noted that $5 \alpha$-androstane-3 $\beta, 17 \beta$-diol, a metabolite of DHT, can stimulate growth in breast cancer cells under severely estrogen-deprived conditions (Sikora et al. 2009, Hanamura et al. 2013). On the other hand, adding aromatizable androgens (androstenedione and testosterone) may result in both anti-proliferative and pro-proliferative influences depending on several variables, i.e. the prevailing activity of estrogen-synthesizing (aromatase) or androgensynthesizing enzymes ( $5 \alpha$-reductase), the relative intracellular expression of ER and AR, and the dose of androgen that was administered. The same rationale applies to carcinogenesis in the animal model. Studies in transgenic male mice overexpressing aromatase (AROM+) have found that the induction of severe gynecomastia and other abnormalities secondary to excessive estrogen production could be reverted by administering aromatase inhibitors (Li et al. 2004, Li 2010, Hickey et al. 2012). These findings provide a clear example of an unbalanced 
androgen/estrogen network: testosterone is mainly converted into estrogens with only a fraction metabolized to DHT, too little to restore the balance.

\section{Supporting evidence for the mechanism of altered androgen/estrogen balance}

There are several papers supporting the central role of androgen excess in breast cancer development: (1) prospective studies in healthy women have consistently shown a strong relationship between high serum androgen levels and increased risk of developing ER-positive breast cancers (Key et al. 2002, Missmer et al. 2004, Cummings et al. 2005). These studies also reported an association between increased risk of breast cancer and high serum levels of estrogens, a finding consistent with increased production of estrogens fueled by high androgen levels; (2) prospective studies in women with ER-positive breast cancer show an increased risk of relapse in patients with high testosterone levels, thus highlighting the role of androgen excess in favoring disease progression (Berrino et al. 2005, Micheli et al. 2007, Emond et al. 2011, Secreto 2012b); (3) ER positivity in tumors was associated with high serum testosterone levels but not with high serum estradiol levels (Secreto et al. 2009, 2011), thus suggesting a direct role of androgens in the development of estrogendependent breast cancers; (4) AR is present in up to $90 \%$ of ER-positive tumors, suggesting once again that the interplay between estrogens and androgens is a crucial determinant in cancer growth (Peters et al. 2009, Suzuki et al. 2010, Fioretti et al. 2014); (5) the abundant expression of androgen-producing enzymes (i.e. 17 $\beta$-hydroxysteroid dehydrogenase type 5 (HSD5) and 5 $\alpha$-reductase) and estrogen-producing enzymes (i.e. 17 $\beta$-HSD1, aromatase and steroid sulfatase) in breast cancer tissue suggests an increased intratumor synthesis of sex hormones leading to an androgen/estrogen balance at a higher level compared to non-cancerous tissue (Suzuki et al. 2003, 2006, 2008, 2010, Bulun et al. 2005, Santen et al. 2009, Nagasaki et al. 2009, Sasano et al. 2009a). Figure 2 shows the biosynthetic pathways of sex steroids in peripheral tissues and the enzymes involved in their production; (6) studies concerning androgens and estrogens concentrations in breast cancer tissue provide further support to our androgen/estrogen imbalance theory. Estradiol levels within breast cancer tissue were found to be significantly higher when compared to non-cancerous tissue and blood levels, suggesting an increase in local production of estrogens from androgen precursors (Van Landeghem et al. 1985, Vermeulen et al. 1986, Mistry et al. 1986,
Recchione et al. 1995, Shibuya et al. 2008, Sasano et al. 2009b, Yaghjyan \& Colditz 2011). Furthermore, Kakugawa et al. (2017) reported an intra-tissue concentration of estradiol about ten times higher in ER-positive compared to ER-negative tumors, while circulating estradiol was similar in the two groups. Only a few papers have dealt with intratumor concentrations of testosterone (Vermeulen et al. 1986, Mistry et al. 1986, Recchione et al. 1995) and DHT (Mistry et al. 1986, Recchione et al. 1995). Intratumor levels of DHT were found to be significantly higher than blood's, with a tissue-to-plasma ratio of 3:1. Suzuki et al. (2006) reported intratumor DHT concentrations similar to those observed in previous studies, though they did not measure DHT serum levels. Shibuya et al. (2008) found a tissue concentration of DHT three times higher in ductal carcinoma in situ than in non-cancerous tissue. The local production of DHT is suggested by the strong correlation between intratumor testosterone and DHT levels ( $r=0.71)$ (Mistry et al. 1986, Recchione et al. 1995). The results from studies on DHT concentration in breast cancer tissue may be interpreted as the cell's attempt to maintain the androgen/estrogen balance by increasing DHT production to counter the excessive estradiol activity. Unlike the sex hormones ratio mentioned above, the tissue/plasma ratio of testosterone was close to one in the few studies that measured it (Vermeulen et al. 1986, Mistry et al. 1986, Recchione et al. 1995). Tumor/plasma testosterone ratio displayed a wide dispersion, ranging from 0.05 to 5.0 in one study (Vermeulen et al. 1986) and from 0.3 to $4.0 \mathrm{in}$ another (Recchione et al. 1995). This implies that tissue testosterone levels were higher than blood testosterone levels in roughly half the tumors while the other half showed higher blood testosterone levels. Whether this finding has biological relevance or not is yet to be established. Nonetheless, we tentatively suggest that elevated intratumor testosterone concentrations might relate to the aromatase pathway of estradiol synthesis, whereas low concentrations might be associated with the sulfatase pathway (Fig. 2).

In conclusion, a large body of evidence supports our hypothesis of androgen excess and androgen/estrogen imbalance as important stimulants of ER-positive tumors development.

\section{Androgen excess in development of ER-negative breast cancer}

The mammary gland is a modified apocrine gland that shares the same embryological origin with salivary and sweat glands (Oftedal 2002, Javed \& Lteif 2013).
C) 2019 Society for Endocrinology Published by Bioscientifica Ltd. Printed in Great Britain 


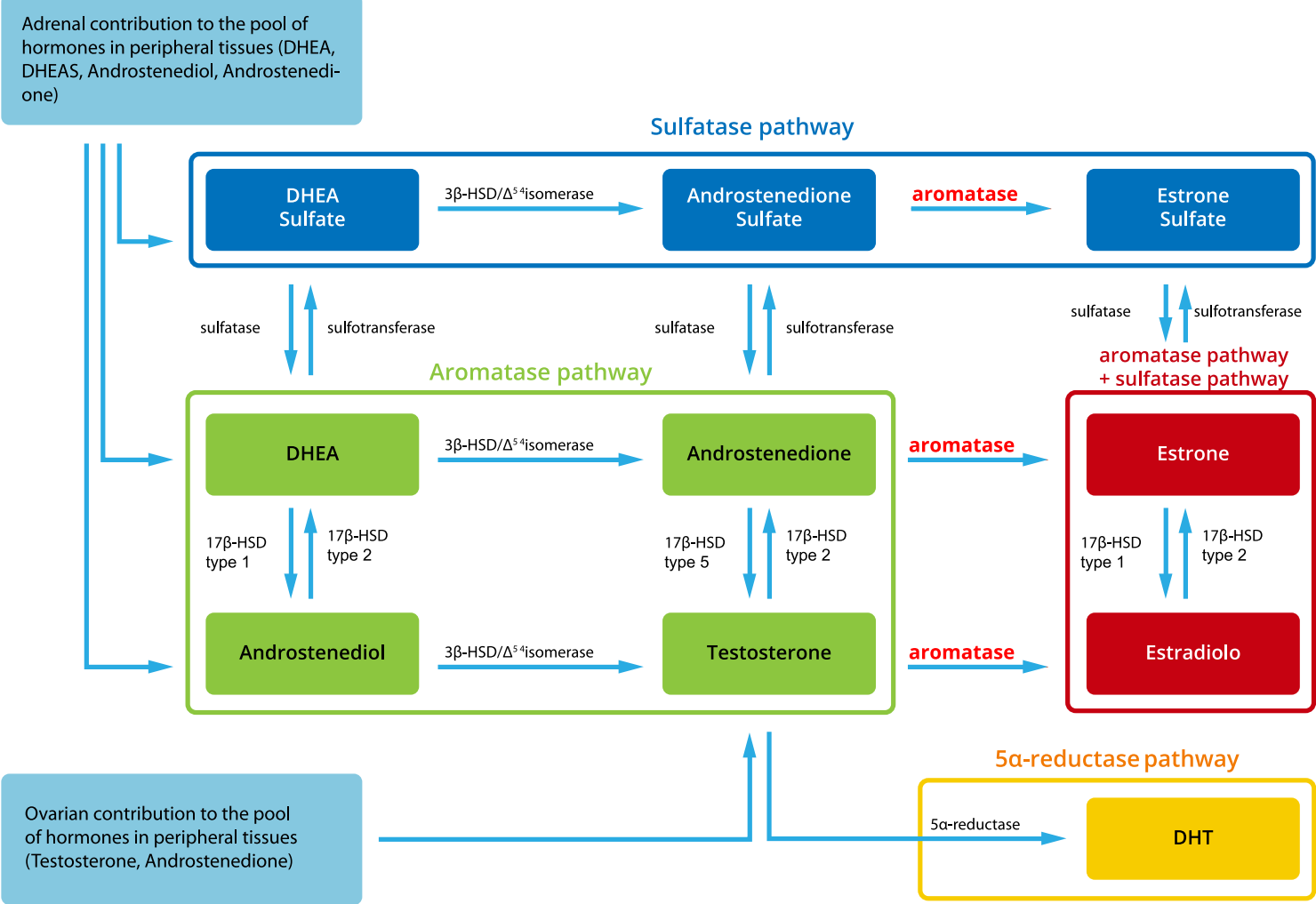

\section{Figure 2}

Simplified illustration of the sex steroids biosynthetic pathway in peripheral tissues after menopause. The two light blue boxes show the contribution of adrenal and ovarian hormones to the pool of peripherally synthesized hormones. Starting from inactive androgen precursors (androstenediol, DHEA, DHEAS), testosterone can be synthesized through several pathways while estrogen formation can only occur by aromatization of androgen precursors, namely androstenedione and testosterone. Two pathways are involved in the synthesis of estradiol: the sulfatase pathway and the aromatase pathway. The activity of sulfatase is counterbalanced by sulfotransferase through the conversion of estrone to estrone sulfate. However, estrogens cannot be reverted to their androgen precursors since there is no 'de-aromatizing enzyme'; thus, aromatase is counterbalanced by the $5 \alpha$-reductase enzyme via DHT synthesis. The interplay between aromatase and $5 \alpha$-reductase in breast cancer cells has been well documented by Suzuki et al. (2006). The figure illustrates the role of androgen precursors in the biosynthesis of estradiol and DHT in support of our androgen/estrogen balance model. It must be noted that DHT may be metabolized to $3 \alpha$-androstanediol and to $3 \beta$-androstanediol by the $3 \alpha$ - and $3 \beta$-HSD enzymes, respectively. These metabolites possess mild estrogenic activity and are capable of stimulating cancer growth in an estrogen-depleted environment (e.g. women undergoing Als therapy). An in-depth analysis of DHT metabolism is covered by the works of McNamara et al. (2014a,b) and Swerdloff (2017). Als, aromatase inhibitors; DHEA, dehydro-epi-androsterone; DHT, dihydrotestosterone; HSD, hydroxysteroid dehydrogenase. Blue box, sulfatase pathway; Green box, aromatase pathway; Red box, aromatase and sulfatase pathway; Yellow box, 5 alfa-reductase.

The apocrine epithelium is influenced by androgens and is an active site for androgen metabolism (Wales \& Ebling 1971, Bradlow et al. 1981, Miller et al. 1985, Bélanger et al. 1990, Lai 1995, Gatalica 1997, Selim \& Wells 1999).

\section{Androgen excess, EGF synthesis and activation of the ErbB family of tyrosine kinase receptors}

Apocrine cysts arise from areas of apocrine metaplasia in the terminal-ductal-lobular-unit (TDLU) (Wellings \& Alpers 1987). They are a common finding in human breasts and are associated with hyperplastic alteration of TDLU and an increased risk of breast cancer (Haagensen et al. 1977, Schuerch et al. 1982, Mazoujian et al. 1983, Dixon et al. 1985, Wellings \& Alpers 1987). Per se, these cysts cannot be regarded as precancerous lesions since cancer rarely arises from their epithelial lining. Therefore, the association of apocrine cysts with hyperplasia and breast cancer hints at a possible common endogenous milieu for cysts growth and for cancer development.

Available evidence shows that (1) apocrine cells are AR positive and ER negative; (2) apocrine cysts are characterized by high concentrations of DHEAS (Bradlow et al. 1981, Miller et al. 1983); (3) studies on apocrine breast cyst fluid composition have shown elevated levels of sex steroids (Bradlow et al. 1981, Boccardo et al. 1988, Bélanger et al. 1990, Angeli et al. 1994, Selim \& Wells 1999, Wells \& El-Ayat 2007) and androgen-induced proteins, namely gross cystic disease fluid proteins and prostatespecific antigen (Haagensen et al. 1977, Mazoujian et al. 
1983, Diamandis et al. 1996, Lai et al. 1996, Malatesta et al. 1999). All together, these findings support the idea of androgens being an important component of the endogenous milieu that favors apocrine cyst growth. Furthermore, a number of studies (Collette et al. 1986, Boccardo et al. 1988, Lai et al. 1989, Pascall 1997, Boccardo et al. 2001) found high levels of epidermal growth factor (EGF), a known stimulant of breast epithelial cell proliferation (Osborne et al. 1980, Lippman et al. 1986, Borellini \& Oka 1989), in apocrine cysts' fluid and assumed that androgens were responsible for EGF secretion in the apocrine cells of the human breast, in analogy with what was observed in the apocrine glands of animals (Wales \& Ebling 1971, Barthe et al. 1974, Sheflin et al. 1996).

The EGF receptor (EGFR), also known as human epidermal growth factor1 (HER1), is part of the ErbB family of tyrosine kinase receptors, together with HER2, HER3 and HER4. The binding of EGF and/or EGF-related peptides (e.g. transforming growth factor-alpha, amphiregulin, heparin binding EGF, betacellulin, neuregulins and others -see Table 1 in Normanno et al. 2001) with EGFR, HER3 and HER4 triggers homo- or heterodimerization of these receptors followed by phosphorylation of receptor tyrosine kinase and activation of the intracellular signaling pathway. However, neither EGF nor EGF-related peptides directly bind with HER2, which is activated by heterodimerization with either EGFR or HER3, or HER4. ErbB receptors, together with their ligands and homo- and hetero-dimers, may interact with each other to form a complex signaling network that influences breast epithelium growth and may favor breast cancer development (Tzahar et al. 1996, Graus-Porta et al. 1997, Normanno et al. 2001, Prenzel et al. 2001, Wieduwilt \& Moasser 2008).

The oncogenic role of androgens in molecular apocrine tumors is well known (Farmer et al. 2005, Doane et al. 2006). In these tumors, AR positivity was repeatedly found associated with an overexpression of HER2, suggesting a cross-talk between the AR and HER2 signaling pathways. These two, in turn, act in synergy to stimulate cell proliferation (Naderi \& Hughes-Davies 2008, Vranic et al. 2010, Chia et al. 2015). Lastly, androgens are capable of inducing cancer proliferation in a certain subgroup of triple-negative tumors, the luminal androgen receptor (LAR), which share several features with molecular apocrine tumors (Lehmann et al. 2011).

The evidence reported above identifies the activation of $\mathrm{AR}$ and ErbB receptors as two pathways for AR-positive/ ER-negative cancer development. We speculate that androgens can trigger both these pathways. Currently,
ER-negative tumors are roughly classified in two molecular subtypes based on the expression of ER, progesterone receptor (PR) and HER2: (1) HER2-enriched subtype comprising ER-negative, PR-negative and HER2-positive tumors; (2) triple-negative tumors (TNBC) (ER-negative, PR-negative and HER2-negative) (McNamara et al. 2014a, Chia et al. 2015, Hon et al. 2016). Overall, approximately $50 \%$ of ER-negative tumors express AR, with a rate of 50-81\% in HER2-positive subtypes and 12-35\% in triplenegative subtypes (Proverbs-Singh et al. 2015).

EGFR is not routinely measured and, as such, is not considered for tumor classification; yet, it is often overexpressed in basal-like tumors, a particularly aggressive subtype of TNBC (Nielsen et al. 2004, Rakha et al. 2007, Cheang et al. 2008, McNamara et al. 2013, 2014b, Changavi et al. 2015). It is plausible that an androgen-driven overproduction of EGF in apocrine breast epithelial cells might also aid tumor growth in EGFR overexpressing non-apocrine tumors.

However, studies concerning the role of androgens in TNBC report lower levels of AR and androgen-synthesizing enzymes (5 $\alpha$-reductase and $17 \beta$-HSD5) in the more aggressive subset of tumors compared to the less aggressive ones (i.e. lower levels in infiltrating cancers that in in situ ones and in basal-like cancers than in non-basal ones) (McNamara et al. 2013, 2014b), thus suggesting a possible protective role of androgens against developing more aggressive subtypes of TNBC. Alternatively, the reduction in $\mathrm{AR}$ and androgen-synthesizing enzymes might be interpreted as an attempt to hinder the androgen-driven excessive EGF production and restore the balance between androgens, EGF and ErbB receptors activation and cell proliferation, through yet unknown regulatory pathways.

Figure 3 illustrates our hypothesis of how the AR and the ErbB pathways may be triggered by androgens during the development of ER-negative/AR-positive tumors.

\section{Anti-androgen therapy in breast cancer}

Emerging evidence of the role of androgens in the development of ER-negative tumors led to consider AR as a viable therapeutic target. The success of preclinical and clinical trials testing for tolerance and antitumor activity of bicalutamide and enzalutamide provided the foundations for phase II clinical trials investigating a possible use of next generation anti-androgen drugs in breast cancer (Proverbs-Singh et al. 2015, Chia et al. 2015, Rahim \& O'Regan 2017). These trials enrolled both ER-negative patients and ER-positive, resistant to anti-estrogen therapy, patients. The latter were included 


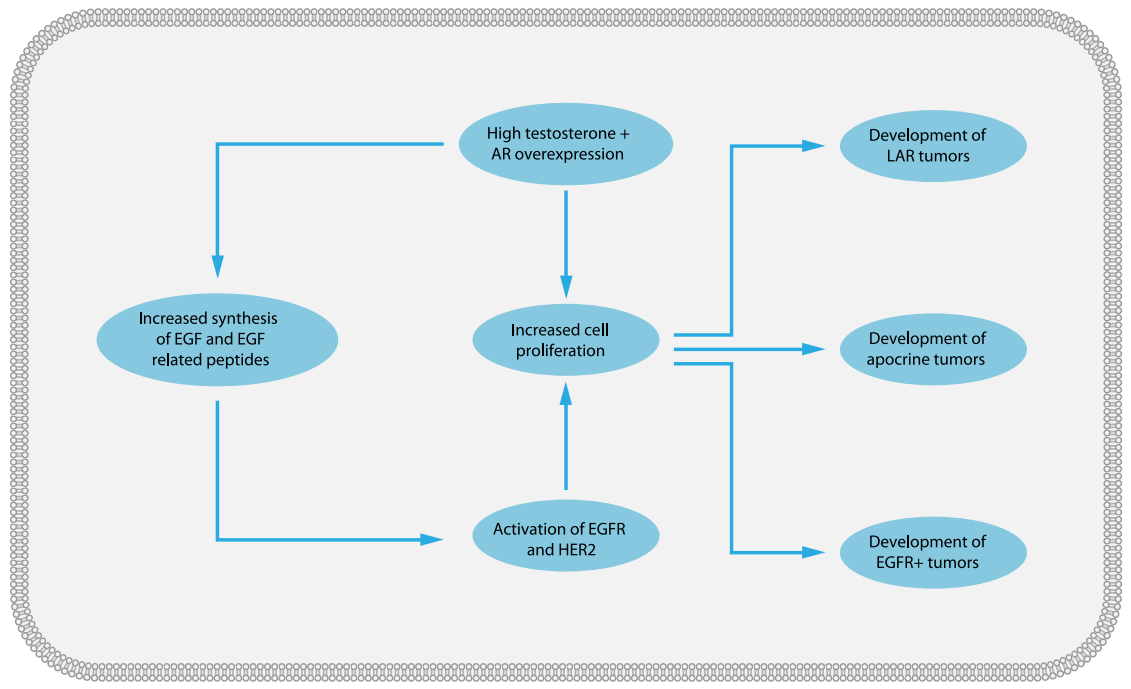

\section{Figure 3}

A diagram of the two pathways that may be activated by androgens in the development of ER-negative breast cancer: AR and ErbB family receptors (EGFR and HER2) pathways. The activation of AR stimulates the development of apocrine and LAR tumors, a subset of triplenegative cancers. Activation of ErbB receptors cooperate in the development of apocrine tumors and might favor the growth of EGFR overexpressing tumors. The role of androgens in the progression of basal-like tumors is unclear, as stated above. AR, androgen receptor; ER, estrogen receptor; EGF, epidermal growth factor, EGFR, epidermal growth factor receptor; HER2, human epidermal growth factor2; LAR, luminal androgen receptor. since overexpression of AR, EGFR and HER2 all are wellknown mechanisms of endocrine resistance (Massarweh et al. 2008, De Amicis et al. 2010, Osborne \& Schiff 2011, Rechoum et al. 2014, Ciupek et al. 2015) that suggest a role of androgens in the activation of both the AR and the ErbB receptors pathways. As a result, addressing this excessive androgen production via AR blockade, alongside standard chemotherapy, might result in better outcomes when compared to conventional treatment alone. However, it must be noted that blocking AR in an androgen-rich environment might cause androgens to shift toward an increased activation of ErbB receptors, thus hindering or even nullifying the initial therapeutic effort with anti-androgens. As previously stated, a reduced expression of AR was found to be associated with more aggressive forms of TNBC, thus suggesting that antiandrogen therapy might not be indicated for this kind of tumors (McNamara et al. 2013, 2014b).

The use of $17 \alpha$ hydroxylase/17-20 lyase (CYP17) inhibitors that block androgen, estrogen and glucocorticoid synthesis is worthy of note. The efficacy of abiraterone acetate, a CYP17 inhibitor, has been evaluated in patients with ER-negative (Bonnefoi et al. 2016) or ER-positive (O'Shaughnessy et al. 2016) metastatic breast cancer and was found to be less than expected. However, studies on abiraterone acetate and other CYP17 inhibitors are still ongoing (Rahim \& O'Regan 2017). A more in-depth analysis of these studies is beyond the scope of this review and has been covered by the works of Proverbs-Singh et al. (2015), Chia et al. (2015), and Rahim \& O'Regan (2017).

Anti-androgen therapy is still at an early stage. The results from ongoing trials might provide more precise recommendations for a potential clinical use. For the time being, the possible role of androgen excess in breast cancer development is certainly gaining momentum and, with it, the opportunity for a novel therapeutic approach.

\section{Clinical implication of androgen excess}

\section{Breast cancer prevention}

Based on our hypothesis on the genesis of ER-positive tumors, addressing the overproduction of androgens in otherwise healthy women may be an effective preventive measure.

Anti-estrogen therapy has been widely proven to reduce the incidence of breast cancer in high-risk healthy women (Goss et al. 2011, Cuzick et al. 2013, Cuzick et al. 2014). However, these drugs cause a steep and symptomatic drop in estrogen levels, with a subsequent worsening in quality of life and, in turn, in poor adherence to therapy (Ropka et al. 2010, Waters et al. 2010). In a recent publication (Secreto et al. 2016), we proposed a treatment regimen with a GnRH analog (i.e. medical ovariectomy) for menopausal women with both high breast cancer risk and high testosterone levels, the latter being a marker of ovarian hyperandrogenemia. The goal of this intervention is to restore the normal balance between androgens and estrogens before the excessive proliferative stimulus results in infiltrating cancer. Furthermore, adherence to therapy is expected to be higher since the choice of GnRH analogs avoids all the severe side effects of hypoestrogenism caused by conventional therapy. 


\section{Adjuvant treatment of early breast cancer}

The goal of hormonal therapy in ER-positive tumors is to block estrogen production. For many years, ER-negative tumors were considered non-hormone dependent thus not responsive to hormonal therapy. Lately, a possible role of androgens in the genesis of these tumors has led to clinical testing of anti-androgen treatment. In this paper we propose a possible role of androgen excess in promoting both ER-positive and ER-negative breast cancer. As a result, the excessive production of androgens might be the common predisposing factor shared by many different tumors; yet, it is not regarded as a possible therapeutic target and hormonal treatment is aimed solely at estrogens and/or the overexpression of HER2 and/or EGFR and/or AR.

The use of anti-estrogen therapy in ER-positive tumors is a clear example of this approach. These drugs are capable of markedly reducing disease progression rates by halting the excessive estrogen synthesis secondary to abnormal androgen production. Furthermore, androgens partake in the endocrine resistance mechanisms (i.e. AR and EGFR overexpression) and are the culprit behind renewed estrogen overproduction and increased risk of late relapse after anti-estrogen discontinuation. Thus, we believe that combining anti-estrogen therapy with the correction of androgen excess might yield better outcomes compared to anti-estrogens alone (Secreto et al. 2017). The same holds true for tumors overexpressing HER2 and EGFR and the ER-negative/AR-positive tumors as well. Once the source of androgen overproduction has been identified via a simple blood assay, it can be addressed with medical ovariectomy, thus providing a useful aid to standard treatment. As a result, we believe that testosterone blood levels should be part of the routine workup for patients with newly diagnosed breast cancer.

We suggest a therapeutic strategy aimed at diagnosing and blocking excessive androgen production, thus differing greatly from the ongoing studies on the efficacy of anti-androgen drugs in advanced stage AR-positive tumors. In particular, our approach cannot be compared to the use of abiraterone acetate in patients heavily pretreated with hormonotherapy, chemotherapy and not selected for their high androgen levels.

\section{Concluding remarks}

This paper dwelled on the mechanisms employed by androgens in regulating breast epithelial growth and suggested how a chronic overproduction of these hormones might be crucial in breast cancer development. It is well established that the cut-off value for elevated androgen blood levels varies between different populations, different laboratories and different analytical methods. As a result, we referred to 'androgen excess' and 'high levels of androgens' to indicate an increased production of these hormones, as reported in the studies setting the diagnostic criteria for hyperandrogenic syndromes (Rotterdam ESHRE/ASRM 2004, Legro et al. 2013, El Hayek et al. 2016). Nonetheless, it must be noted that androgens play a crucial role in cell proliferation regardless of the criteria defining their overproduction.

We highlighted how androgen excess and breast cancer are associated regardless of the source of the overproduction. With the exception of dire ailments such as androgen-secreting tumors, Cushing's syndrome and classical congenital adrenal hyperplasia (CAH), the main etiologies of hyperandrogenism are ovarian stromal hyperplasia, polycystic ovarian syndrome (PCOS) and non-classical CAH.

Ovarian stromal hyperplasia is consistently found within polycystic ovaries and often is present in postmenopausal ovaries, ranging from low to medium up to severe grade.

In their 1952 paper, Sommers \& Teloh reported ovarian stromal hyperplasia in 83 out of 100 deceased breast cancer patients and in 50 out of 133 deceased women (37.6\%) without any discernable malignancy after autopsy (Sommers \& Teloh 1952). The authors concluded that ovarian stromal hyperplasia was more frequent and of a higher grade in cancer patients compared to noncancer patients.

A number of studies showed an association between androgen levels within ovarian veins and the grade of stromal hyperplasia with a steady drop in testosterone and androstenedione levels after ovariectomy (Lucisano et al. 1986, Sluijmer et al. 1998, Jongen et al. 2003, Secreto et al. 2016). The papers cited above support the link between ovarian stromal hyperplasia, increased androgen production and breast cancer.

PCOS is a common endocrine disorder among fertile women defined as hyperandrogenism (diagnosed with clinical signs and symptoms or laboratoristically) and chronic anovulation, with or without a polycystic appearance of the ovaries (Rotterdam ESHRE/ASRM 2004, Azziz et al. 2006, Legro et al. 2013, Dumesic et al. 2015, El Hayek et al. 2016). Hyperandrogenism is responsible for anovulatory cycles, ovarian stromal hyperplasia and is associated with insulin resistance, obesity, dyslipidemia and thus is considered a key factor in the development https://erc bioscientifica.com https://doi.org/10.1530/ERC-18-0429 (c) 2019 Society for Endocrinology Published by Bioscientifica Ltd. Printed in Great Britain 
Table 1 Summary of the possible role of androgen excess in the development of different subsets of breast cancer.

\begin{tabular}{l} 
Mechanisms of growth stimulation \\
\hline Androgen excess \\
Conversion to estrogens and activation of the ER pathway \\
Binding to AR and activation of the AR pathway \\
Increased production of EGF and activation of the \\
ErbB receptors family
\end{tabular}

\section{Tumor type}

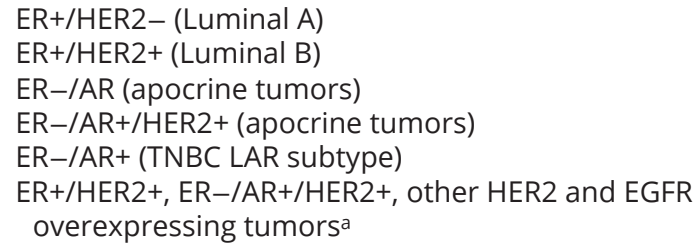

aln theory, androgens are capable of indirect stimulation of all HER2 and EGFR overexpressing tumors; yet, there is still insufficient evidence to support our claim. We discussed in the main text above how androgens are likely to protect against the development of basal-like TNBC.

$A R$, androgen receptor; ER, estrogen receptor; EGF, epidermal growth factor; EGFR, epidermal growth factor receptor; HER2, human epidermal growth factor2; LAR, luminal androgen receptor; TNBC, triple-negative breast cancer.

of PCOS (Azziz et al. 2006, Dumesic et al. 2015). High androgen levels, infertility, ovarian stromal hyperplasia, obesity and insulin resistance are all linked to an increased risk of developing breast cancer. As a result, a strong relationship between PCOS and breast cancer would be expected yet current evidence does not support this association. (Coulam et al. 1983, Balen 2001, Ghasemi et al. 2010, Barry et al. 2014, Shen et al. 2015). There is a general agreement on how the variability among the PCOS' diagnostic criteria can mislead risk evaluation.

PCOS is a complex syndrome with genetic, metabolic and environmental factors all concurring in yielding different clinical manifestations. Alongside the classical phenotype (defined as hyperandrogenism and chronic anovulation with or without the polycystic appearance of the ovaries) milder forms are present such as non-classical ovulatory PCOS (i.e. hyperandrogenism, polycystic ovaries, regular menstrual cycles) and non-classical mild or normoandrogenic PCOS (i.e. chronic anovulation, polycystic ovaries, normal androgens) (El Hayek et al. 2016). Such a wide range of clinical manifestations suggests that women with non-classical PCOS might be deemed normal when the hyperandrogenism and the metabolic derangements are asymptomatic. In time, these women are more likely to develop PCOS-associated morbidities (i.e. obesity, insulin resistance and dyslipidemia) and, we believe, are at a greater risk of developing breast cancer.

This hypothesis would partially explain the inconsistencies that emerged from the studies on breast cancer risk in PCOS patients, since non-classical PCOS women might have been assigned to the control group. For instance, in some studies, the diagnosis of PCOS among the subjects was solely based on self-certification provided by the patients themselves (Balen 2001, Barry et al. 2014).

$\mathrm{CAH}$ is an autosomal recessive disorder caused by a deficiency of the 21-hydroxylase enzyme, characterized by insufficient cortisol production and excessive androgen synthesis. The non-classical variant is quite frequent, albeit a precise estimate of its incidence in the general population is unobtainable due to the oftenmild symptoms and late onset (Speiser et al. 1985, Merke \& Bornstein 2005, New 2006, Bidet et al. 2010). Women affected by this variant will only have a slight cortisol deficiency and some of them require no therapy to live a normal life. Signs of hyperandrogenism, such as hypertrichosis, menstrual irregularity, infertility and, in some cases, PCOS, are present and may vary in intensity (Merke \& Bornstein 2005, New 2006). All the guidelines for the diagnosis of PCOS (El Hayek et al. 2016) require the exclusion of $\mathrm{CAH}$, since the two conditions share common traits such as hyperandrogenism.

Just as mentioned before regarding the non-classical PCOS, we believe that women with undiagnosed nonclassical CAH might be part of the general population and thus considered normal. This can introduce an additional confounding factor in those studies regarding breast cancer risk in PCOS patients.

A summary table (Table 1) of our hypothesis on the role of androgens in the development of different subsets of breast cancer concludes this section.

\section{Conclusion}

Breast cancer is a hormone-dependent disease that encompasses biologically and clinically different tumor types. In the past years, basic research led to a better understanding of the different subtypes of breast cancer and, consequently, to a substantial improvement in therapy.

The aim of this review is to offer clinicians and researchers a novel approach to breast cancer development by emphasizing the pivotal role of androgen excess. We believe that there is sufficient evidence in the literature to (c) 2019 Society for Endocrinology Published by Bioscientifica Ltd. Printed in Great Britain 
support a randomized clinical trial. This may prove how correcting an excessive androgen production is beneficial to both prevent and treat breast cancer. We are well aware that some of our conclusions might be modified by new findings in this ever-changing field of research. Still, we are certain that our fresh approach to this somewhat unexplored matter might yield significant results and further deepen our understanding of breast cancer.

\section{Declaration of interest}

The authors declare that there is no conflict of interest that could be perceived as prejudicing the impartiality of this review.

\section{Funding}

This work did not receive any specific grant from any funding agency in the public, commercial or not-for-profit sector.

\section{Acknowledgements}

The authors wish to thank Stefano Colma for the illustrations.

\section{References}

Angeli A, Dogliotti L, Naldoni C, Orlandi F, Puligheddu B, Caraci P, Bucchi L, Torta M \& Bruzzi P 1994 Steroid biochemistry and categorization of breast cyst fluid: relation to breast cancer risk. Journal of Steroid Biochemistry and Molecular Biology 49 333-339. (https://doi.org/10.1016/0960-0760(94)90276-3)

Azziz R, Carmina E, Dewailly D, Diamanti-Kandarakis E, EscobarMorreale HF, Futterweit W, Janssen OE, Legro RS, Norman RJ, Taylor AE, et al. 2006 Positions statement: criteria for defining polycystic ovary syndrome as a predominantly hyperandrogenic syndrome: an Androgen Excess Society guideline. Journal of Clinical Endocrinology and Metabolism 91 4237-4245. (https://doi. org/10.1210/jc.2006-0178)

Balen A 2001 Polycystic ovary syndrome and cancer. Human Reproduction Update 7 522-525. (https://doi.org/10.1093/humupd/7.6.522)

Barry JA, Azizia MM \& Hardiman PJ 2014 Risk of endometrial, ovarian and breast cancer in women with polycystic ovary syndrome: a systematic review and meta-analysis. Human Reproduction Update 20 748-758. (https://doi.org/10.1093/humupd/dmu012)

Barthe PL, Bullock LP, Mowszowicz I, Bardin CW \& Orth DN 1974 Submaxillary gland epidermal growth factor: a sensitive index of biologic androgen activity. Endocrinology 95 1019-1025. (https://doi. org/10.1210/endo-95-4-1019)

Bélanger A, Labrie F \& Angeli A 1990 Unconjugated and glucuronide steroid levels in human breast cyst fluid. Annals of the New York Academy of Sciences 586 93-100. (https://doi. org/10.1111/j.1749-6632.1990.tb17795.x)

Berrino F, Pasanisi P, Bellati C, Venturelli E, Krogh V, Mastroianni A, Berselli E, Muti P \& Secreto G 2005 Serum testosterone levels and breast cancer recurrence. International Journal of Cancer 113 499-502. (https://doi.org/10.1002/ijc.20582)

Bidet M, Bellanné-Chantelot C, Galand-Portier MB, Golmard JL, Tardy V, Morel Y, Clauin S, Coussieu C, Boudou P, Mowzowicz I, et al. 2010 Fertility in women with nonclassical congenital adrenal hyperplasia due to 21-hydroxylase deficiency. Journal of Clinical Endocrinology and Metabolism 95 1182-1190. (https://doi.org/10.1210/jc.2009-1383)
Boccardo F, Valenti G, Zanardi S, Cerruti G, Fassio T, Bruzzi P, De Franchis V, Barreca A, Del Monte P \& Minuto F 1988 Epidermal growth factor in breast cyst fluid: relationship with intracystic cation and androgen conjugate content. Cancer Research 48 5860-5863. (https://doi.org/10.1002/ijc.2910470409)

Boccardo F, Marenghi C, Ghione G, Pepe A, Parodi S \& Rubagotti A 2001 Intracystic epidermal growth factor level is predictive of breast-cancer risk in women with gross cystic disease of the breast. International Journal of Cancer 295 260-265. (https://doi.org/10.1002/10970215(20010720)95:4<260::AID-IJC1044>3.0.CO;2-N)

Bonnefoi H, Grellety T, Tredan O, Saghatchian M, Dalenc F, Mailliez A, L'Haridon T, Cottu P, Abadie-Lacourtoisie S, You B, et al. 2016 A phase II trial of abiraterone acetate plus prednisone in patients with triple-negative androgen receptor positive locally advanced or metastatic breast cancer (UCBG 12-1). Annals of Oncology 27 812-818. (https://doi.org/10.1093/annonc/mdw067)

Borellini F \& Oka T 1989 Growth control and differentiation in mammary epithelial cells. Environmental Health Perspectives 80 85-89. (https://doi.org/10.2307/3430734)

Bradlow HL, Rosenfeld RS, Kream J, Fleisher M, O'Connor J \& Schwartz MK 1981 Steroid hormone accumulation in human breast cyst fluid. Cancer Resarch 41 105-107.

Bulun SE, Lin Z, Imir G, Amin S, Demura M, Yilmaz B, Martin R, Utsunomiya H, Thung S, Gurates B, et al. 2005 Regulation of aromatase expression in estrogen-responsive breast and uterine disease: from bench to treatment. Pharmacological Reviews $\mathbf{5 7}$ 359-383. (https://doi.org/10.1124/pr.57.3.6)

Carter AC, Sedransk N, Kelley RM, Ansfield FJ, Ravdin RG, Talley RW \& Potter NR 1977 Diethylstilbestrol: recommended dosages for different categories of breast cancer patients. Report of the Cooperative Breast Cancer Group. JAMA 237 2079-2085. (https:// doi.org/10.1001/jama.1977.03270460065023)

Casey RW \& Wilson JD 1984 Antiestrogenic action of dihydrotestosterone in mouse breast. Competition with estradiol for binding to the estrogen receptor. Journal of Clinical Investigation $\mathbf{7 4}$ 2272-2278. (https://doi.org/10.1172/JCI111654)

Changavi AA, Shashikala A \& Ramji AS 2015 Epidermal growth factor receptor expression in triple negative and nontriple negative breast carcinomas. Journal of Laboratory Physicians 7 79-83. (https://doi. org/10.4103/0974-2727.163129)

Cheang MC, Voduc D, Bajdik C, Leung S, McKinney S, Chia SK, Perou CM \& Nielsen TO 2008 Basal-like breast cancer defined by five biomarkers has superior prognostic value than triple-negative phenotype. Clinical Cancer Research 14 1368-1376. (https://doi. org/10.1158/1078-0432.CCR-07-1658)

Chia K, O'Brien M, Brown M \& Lim E 2015 Targeting the androgen receptor in breast cancer. Current Oncology Reports 17 4. (https://doi. org/10.1007/s11912-014-0427-8)

Choi J, Psarommatis B, Gao YR, Zheng Y, Handelsman DJ \& Simanainen U 2014 The role of androgens in experimental rodent mammary carcinogenesis. Breast Cancer Research 16 483. (https://doi. org/10.1186/s13058-014-0483-x)

Ciupek A, Rechoum Y, Gu G, Gelsomino L, Beyer AR, Brusco L, Covington KR, Tsimelzon A \& Fuqua SA 2015 Androgen receptor promotes tamoxifen agonist activity by activation of EGFR in ER $\alpha$ positive breast cancer. Breast Cancer Research and Treatment 154 225-237. (https://doi.org/10.1007/s10549-015-3609-7)

Collette J, Hendrick JC, Jaspar JM \& Franchimont P 1986 Presence of alpha-lactalbumin, epidermal growth factor, epithelial membrane antigen, and gross cystic disease fluid protein (15,000 daltons) in breast cyst fluid. Cancer Research 46 3728-3733.

Coulam CB, Annegers JF \& Kranz JS 1983 Chronic anovulation syndrome and associated neoplasia. Obstetrics and Gynecology 61 403-407.

Cummings SR, Lee JS, Lui LY, Stone K, Ljung BM \& Cauleys JA 2005 Sex hormones, risk factors, and risk of estrogen receptor-positive breast https://erc bioscientifica com

https://doi.org/10.1530/ERC-18-0429
2019 Society for Endocrinology Published by Bioscientifica Ltd. Printed in Great Britain 
cancer in older women: a long-term prospective study. Cancer Epidemiology, Biomarkers and Prevention 14 1047-1051. (https://doi. org/10.1158/1055-9965.EPI-04-0375)

Cunha GR 1994 Role of mesenchymal-epithelial interaction in normal and abnormal development of the mammary gland and prostate. Cancer 74 (Supplement 3) 1030-1044. (https://doi.org/10.1002/10970142(19940801)74:3+<1030::AID-CNCR2820741510>3.0.CO;2-Q)

Cuzick J, Sestak I, Bonanni B, Costantino JP, Cummings S, De Censi A, Dowsett M, Forbes JF, Ford L, LaCroix AZ, et al. 2013 SERM chemoprevention of breast cancer overview group. Selective oestrogen receptor modulators in prevention of breast cancer: an updated meta-analysis of individual participant data. Lancet $\mathbf{3 8 1}$ 1827-1834. (https://doi.org/10.1016/S0140-6736(13)60140-3)

Cuzick J, Sestak I, Forbes JF, Dowsett M, Knox J, Cawthorn S, Saunders C, Roche N, Mansel RE, von Minckwitz G, et al. 2014 Anastrozole for prevention of breast cancer in high-risk postmenopausal women (IBIS-II): an international, double-blind, randomized placebo-controlled trial. Lancet 383 1041-1048. (https:// doi.org/10.1016/S0140-6736(13)62292-8)

De Amicis F, Thirugnansampanthan J, Cui Y, Selever J, Beyer A, Parra I, Weigel NL, Herynk MH, Tsimelzon A, Lewis MT, et al. 2010 Androgen receptor overexpression induces tamoxifen resistance in human breast cancer cells. Breast Cancer Research and Treatment 121 1-11. (https://doi.org/10.1007/s10549-009-0436-8)

Diamandis EP, Yu H \& López-Otín C 1996 Prostate specific antigen - a new constituent of breast cyst fluid. Breast Cancer Research and Treatment 38 259-264. (https://doi.org/10.1007/BF01806144)

Dixon JM, Lumdsen AB \& Miller WR 1985 The relationship of cyst type to risk factors for breast cancer and the subsequent development of breast cancer in patients with breast cystic disease. European Journal of Cancer and Clinical Oncology 21 1047-1050. (https://doi. org/10.1016/0277-5379(85)90289-5)

Doane AS, Danso M, Lal P, Donaton M, Zhang L, Hudis C \& Gerald WL 2006 An estrogen receptor-negative breast cancer subset characterized by a hormonally regulated transcriptional program and response to androgen. Oncogene 25 3994-4008. (https://doi. org/10.1038/sj.onc.1209415)

Dumesic DA, Oberfield SE, Stener-Victorin E, Marshall JC, Laven JS \& Legro RS 2015 Scientific statement on the diagnostic criteria, epidemiology, pathophysiology, and molecular genetics of polycystic ovary syndrome. Endocrine Reviews 36 487-525. (https://doi. org/10.1210/er.2015-1018)

Elebro K, Borgquist S, Simonsson M, Markkula A, Jirström K, Ingvar C, Rose C \& Jernström H 2015 Combined androgen and estrogen receptor status in breast cancer: treatment prediction and prognosis in a population-based prospective cohort. Clinical Cancer Research $\mathbf{2 1}$ 3640-3650. (https://doi.org/10.1158/1078-0432.CCR-14-2564)

El Hayek S, Bitar L, Hamdar LH, Mirza FG \& Daoud G 2016 Poly cystic ovarian syndrome: an updated overview. Frontiers in Physiology $\mathbf{7}$ 124. (https://doi.org/10.3389/fphys.2016.00124)

Emond JA, Patterson RE, Natarajan L, Laughlin GA, Gold EB \& Pierce JP 2011 Sex hormone concentrations and the risk of breast cancer recurrence in postmenopausal women without hot flashes. Cancer Epidemiology, Biomarkers and Prevention 20 939-945. (https://doi. org/10.1158/1055-9965)

Farmer P, Bonnefoi H, Becette V, Tubiana-Hulin M, Fumoleau P, Larsimont D, Macgrogan G, Bergh J, Cameron D, Goldstein D, et al. 2005 Identification of molecular apocrine breast tumours by microarray analysis. Oncogene 24 4660-4671. (https://doi. org/10.1038/sj.onc.1208561)

Fioretti FM, Sita-Lumsden A, Bevan CL \& Brooke GN 2014 Revising the role of the androgen receptor in breast cancer. Journal of Molecular Endocrinology 52 R257-R265. (https://doi.org/10.1530/ JME-14-0030)

Fleming JM, Miller TC, Quinones M, Xiao Z, Xu X, Meyer MJ, Ginsburg E, Veenstra TD \& Vonderhaar BK 2010 The normal breast microenvironment of premenopausal women differentially influences the behavior of breast cancer cells in vitro and in vivo. BMC Medicine 8, 27. (https://doi.org/10.1186/1741-7015-8-27)

Ghasemi N, Reza Mortazavizadeh M \& Aboolfazl Khorasani Gerdekoohi AK 2010 Frequency of poly cystic ovary syndrome in patients with premenopausal breast cancer. Iranian Journal of Reproductive Medicine 8 86-89.

Gatalica Z 1997 Immunohistochemical analysis of apocrine breast lesions. Consistent over-expression of androgen receptor accompanied by the loss of estrogen and progesterone receptors in apocrine metaplasia and apocrine carcinoma in situ. PathologyResarch and Practice 193 753-758. (https://doi.org/10.1016/S03440338(97)80053-2)

Goldenberg IS 1964 Testosterone propionate therapy in breast cancer. JAMA 188 1069-1072. (https://doi.org/10.1001/ jama.1964.03060380037009)

Goss PE, Ingle JN, Ales-Martınez JE, Cheung AM, Chlebowski RT, Wactawski-Wende J, McTiernan A, Robbins J, Johnson KC, Martin LW, et al. 2011 Exemestane for breast cancer prevention in postmenopausal women. New England Journal of Medicine $\mathbf{3 6 4}$ 2381-2391. (https://doi.org/10.1056/NEJMoa1103507)

Graus-Porta D, Beerli RR, Daly JM \& Hynes NE 1997 ErbB-2, the preferred heterodimerization partner of all ErbB receptors, is a mediator of lateral signaling. EMBO Journal 16 1647-1655. (https:// doi.org/10.1093/emboj/16.7.1647)

Haagensen DE Jr, Mazoujian G, Holder WD Jr, Kister SJ \& Wells SA Jr 1977 Evaluation of a breast cyst fluid protein detectable in the plasma of breast carcinoma patients. Annals of Surgery 185 279-285. (https://doi.org/10.1097/00000658-197703000-00005)

Hanamura T, Niwa T, Nishikawa S, Konno H, Gohno T, Tazawa C, Kobayashi Y, Kurosumi M, Takei H, Yamaguchi Y, et al. 2013 Androgen metabolite-dependent growth of hormone receptorpositive breast cancer as a possible aromatase inhibitor-resistance mechanism. Breast Cancer Research and Treatment 139 731-740. (https://doi.org/10.1007/s10549-013-2595-x)

Hickey TE, Robinson JL, Carroll JS \& Tilley WD 2012 Minireview: the androgen receptor in breast tissues: growth inhibitor, tumor suppressor, oncogene? Journal of Molecular Endocrinology 26 1252-1267. (https://doi.org/10.1210/me.2012-1107)

Hon JD, Singh B, Sahin A, Du G, Wang J, Wang VY, Deng FM, Zhang DY, Monaco ME \& Lee P 2016 Breast cancer molecular subtypes: from TNBC to QNBC. American Journal of Cancer Research 6 1864-1872.

Hortobagyi GN, Buzdar AU, Frye D, Yap HY, Hug V, Pinnamaneni K, Fraschini G, Halvorson HC \& Blumenschein GR 1985 Oral medroxyprogesterone acetate in the treatment of metastatic breast cancer. Breast Cancer Research and Treatment 5 321-326. (https://doi. org/10.1007/BF01806027)

Hu R, Dawood S, Holmes MD, Collins LC, Schnitt SJ, Cole K, Marotti JD, Hankinson SE, Colditz GA \& Tamimi RM 2011 Androgen receptor expression and breast cancer survival in postmenopausal women. Clinical Cancer Research 17 1867-1874. (https://doi. org/10.1158/1078-0432.CCR-10-2021)

Imagawa W, Pedchenko VK, Helber J \& Zhang H 2002 Hormone/growth factor interactions mediating epithelial/stromal communication in mammary gland development and carcinogenesis. Journal of Steroid Biochemistry and Molecular Biology 80 213-230. (https://doi. org/10.1016/S0960-0760(01)00188-1)

Ingle JN 2002 Estrogen as therapy for breast cancer. Breast Cancer Research 4 133-136. (https://doi.org/10.1186/bcr436)

Iwase H, Yamamoto Y, Yamamoto-Ibusuki M, Murakami KI, Okumura Y, Tomita S, Inao T, Honda Y, Omoto Y \& Iyama KI 2013 Ethinylestradiol is beneficial for postmenopausal patients with heavily pre-treated metastatic breast cancer after prior aromatase inhibitor treatment: a prospective study. British Journal of Cancer 109 1537-1542. (https://doi.org/10.1038/bjc.2013.520) (c) 2019 Society for Endocrinology Published by Bioscientifica Ltd. Printed in Great Britain 
Javed A \& Lteif A 2013 Development of the human breast. Seminars in Plastic Surgery 27 5-12. (https://doi.org/10.1055/s-0033-1343989)

Jongen VHWM, Holleman H, van der Zee AGJ, Santema JG \& Heineman MJ 2003 Ovarian stromal hyperplasia and ovarian vein steroid levels in relation to endometrioid endometrial cancer. British Journal of Obstetrics and Gynaecology 110 690-695. (https://doi. org/10.1046/j.1471-0528.2003.02389.x)

Kakugawa Y, Tada H, Kawai M, Suzuki T, Nishino Y, Kanemura S, Ishida T, Ohuchi N \& Minami Y 2017 Associations of obesity and physical activity with serum and intratumoral sex steroid hormone levels among postmenopausal women with breast cancer: analysis of paired serum and tumor tissue samples. Breast Cancer Research and Treatment 162 115-125. (https://doi.org/10.1007/s10549-016-4094-3)

Key T, Appleby P, Barnes I \& Reeves G 2002 Endogenous sex hormones and breast cancer in postmenopausal women: reanalysis of nine prospective studies. Journal of the National Cancer Institute $\mathbf{9 4}$ 606-616. (https://doi.org/10.1093/jnci/94.8.606)

Lai LC 1995 Metabolism of dehydroepiandrosterone sulphate by breast cysts: possible role in the development of breast cancer. Cancer Detection and Prevention 19 441-445.

Lai LC, Ghilchik MW, Shaikh NA, Reed MJ \& James VH 1989 Relationship between epidermal growth factor and dehydroepiandrosterone and its sulphate in breast cyst fluid. British Journal of Cancer 60 320-323. (https://doi.org/10.1038/bjc.1989.278)

Lai LC, Erbas H, Lennard TW \& Peaston RT 1996 Prostate-specific antigen in breast cyst fluid: possible role of prostate-specific antigen in hormone-dependent breast cancer. International Journal of Cancer 66 743-746. (https://doi.org/10.1002/(SICI)10970215(19960611)66:6<743::AID-IJC6>3.0.CO;2-\#)

Legro RS, Arslanian SA, Ehrmann DA, Hoeger KM, Murad MH, Pasquali R \& Welt CK 2013 Diagnosis and treatment of polycystic ovary syndrome: an Endocrine Society clinical practice guideline. Journal of Clinical Endocrinology and Metabolism 98 4565-4592. (https://doi.org/10.1210/jc.2013-2350)

Lehmann BD, Bauer JA, Chen X, Sanders ME, Chakravarthy AB, Shyr Y \& Pietenpol JA 2011 Identification of human triple-negative breast cancer subtypes and preclinical models for selection of targeted therapies. Jounal of Clinical Investigation 121 2750-2767. (https://doi. org/10.1172/JCI45014)

Li X 2010 Aromatase over expression transgenic murine models for aromatase inhibitor studies. Molecular Human Reproduction 16 80-86. (https://doi.org/10.1093/molehr/gap070)

Li X, Strauss L, Mäkelä S, Streng T, Huhtaniemi I, Santti R \& Poutanen M 2004 Multiple structural and functional abnormalities in the p450 aromatase expressing transgenic male mice are ameliorated by a p450 aromatase inhibitor. American Journal of Pathology 164 1039-1048. (https://doi.org/10.1016/S00029440(10)63191-4)

Liao DJ \& Dickson R 2002 Roles of androgens in the development, growth, and carcinogenesis of the mammary gland. Journal of Steroid Biochemistry and Molecular Biology 80 175-189. (https://doi. org/10.1016/S0960-0760(01)00185-6)

Lippman ME, Dickson RB, Kasid A, Gelmann E, Davidson N, McManaway M, Huff K, Bronzert D, Bates S, Swain S, et al. 1986 Autocrine and paracrine growth regulation of human breast cancer. Journal of Steroid Biochemistry 24 147-154. (https://doi. org/10.1016/0022-4731(86)90044-0)

Lucisano A, Russo N, Acampora MG, Fabiano A, Fattibene M, Parlati E, Maniccia E \& Dell'Acqua S 1986 Ovarian and peripheral androgen and oestrogen levels in post-menopausal women: correlations with ovarian histology. Maturitas 8 57-65. (https://doi.org/10.1016/03785122(86)90008-3)

Malatesta M, Mannello F, Sebastiani M, Bianchi G \& Gazzanelli G 1999 Prostate-specific antigen found in type I breast cyst fluids is a secretory product of the apocrine cells lining breast gross cysts.
Breast Cancer Research and Treatment 57 157-163. (https://doi. org/10.1023/A:1006182518520)

Massarweh S, Osborne CK, Creighton CJ, Qin L, Tsimelzon A, Huang S, Weiss H, Rimawi M \& Schiff R 2008 Tamoxifen resistance in breast tumors is driven by growth factor receptor signaling with repression of classic estrogen receptor genomic function. Cancer Research $\mathbf{6 8}$ 826-833. (https://doi.org/10.1158/0008-5472.CAN-07-2707)

Mazoujian G, Pinkus GS, Davis S \& Haagensen DE Jr. 1983 Immunohistochemistry of a gross cystic disease fluid protein (GCDFP-15) of the breast. A marker of apocrine epithelium and breast carcinomas with apocrine features.American Journal of Pathology 110 105-112.

McNamara KM, Yoda T, Miki Y, Chanplakorn N, Wongwaisayawan S, Incharoen P, Kongdan Y, Wang L, Takagi K, Mayu T, et al. 2013 Androgenic pathway in triple negative invasive ductal tumors: its correlation with tumor cell proliferation. Cancer Science $\mathbf{1 0 4}$ 639-646. (https://doi.org/10.1111/cas.12121)

McNamara KM, Moore NL, Hickey TE, Sasano H \& Tilley WD $2014 a$ Complexities of androgen receptor signalling in breast cancer. EndocrineRelated Cancer 21 T161-T181. (https://doi.org/10.1530/ERC-14-0243)

McNamara KM, Yoda T, Nurani AM, Shibahara Y, Miki Y, Wang L, Nakamura Y, Suzuki K, Yang Y, Abe E, et al. 2014b Androgenic pathways in the progression of triple-negative breast carcinoma: a comparison between aggressive and non-aggressive subtypes. Breast Cancer Research and Treatment 145 281-293. (https://doi.org/10.1007/ s10549-014-2942-6)

Merke DP \& Bornstein SR 2005 Congenital adrenal hyperplasia. Lancet 365 2125-2136. (https://doi.org/10.1016/S0140-6736(05)66736-0)

Micheli A, Meneghini E, Secreto G, Berrino F, Venturelli E, Cavalleri A, Camerini T, Di Mauro MG, Cavadini E, De Palo G, et al. 2007 Plasma testosterone and prognosis of postmenopausal breast cancer patients. Journal of Clinical Oncology 25 2685-2690. (https://doi.org/10.1200/ JCO.2006.09.0118)

Miller WR, Dixon JM, Scott WN \& Forrest AP 1983 Classification of human breast cysts according to electrolyte and androgen conjugate composition. Clinical Oncology 9 227-232.

Miller WR, Telford J, Dixon JM \& Shivas AA 1985 Androgen metabolism and apocrine differentiation in human breast cancer. Breast Cancer Research and Treatment 5 67-73. (https://doi.org/10.1007/ BF01807652)

Missmer SA, Eliassen AH, Barbieri RL, \& Hankinson SE 2004 Endogenous estrogen, androgen, and progesterone concentrations and breast cancer risk among postmenopausal women. Journal of the National Cancer Institute 96 1856-1865. (https://doi.org/10.1093/jnci/djh336)

Mistry P, Griffiths K \& Maynard PV 1986 Endogenous C19-steroids and oestradiol levels in human primary breast tumour tissues and their correlation with androgen and oestrogen receptors. Journal of Steroid Biochemistry 24 1117-1125. (https://doi.org/10.1016/00224731(86)90372-9)

Naderi A \& Hughes-Davies L 2008 A functionally significant cross-talk between androgen receptor and ErbB2 pathways in estrogen receptor negative breast cancer. Neoplasia 10 542-548. (https://doi. org/10.1593/neo.08274)

Nagasaki S, Miki Y, Akahira J, Suzuki T \& Sasano H 2009 17betahydroxysteroid dehydrogenases in human breast cancer. Annals of the New York Academy of Sciences 1155 25-32. (https://doi. org/10.1111/j.1749-6632.2008.03682.x.)

New MI 2006 Extensive clinical experience: nonclassical 21-hydroxylase deficiency. Journal of Clinical Endocrinology and Metabolism 91 4205-4214. (https://doi.org/10.1210/jc.2006-1645)

Nielsen TO, Hsu FD, Jensen K, Cheang M, Karaca G, Hu Z, HernandezBoussard T, Livasy C, Cowan D, Dressler L, et al. 2004 Immunohistochemical and clinical characterization of the basal-like subtype of invasive breast carcinoma. Clinical Cancer Research 10 5367-5374. (https://doi.org/10.1158/1078-0432.CCR-04-0220) (c) 2019 Society for Endocrinology Published by Bioscientifica Ltd. Printed in Great Britain 
Niemeier LA, Dabbs DJ, Beriwal S, Striebel JM \& Bhargava R 2010 Androgen receptor in breast cancer: expression in estrogen receptorpositive tumors and in estrogen receptor-negative tumors with apocrine differentiation. Modern Pathology 23 205-212. (https://doi. org/10.1038/modpathol.2009.159)

Normanno N, Bianco C, De Luca A \& Salomon DS 2001 The role of EGF-related peptides in tumor growth. Frontiers in Bioscience 6 D685-D707. (https://doi.org/10.2741/A635)

Oftedal OT 2002 The mammary gland and its origin during synapsid evolution. Journal of Mammary Gland Biology and Neoplasia 7 225-252. (https://doi.org/10.1023/A:1022896515287)

Osborne CK \& Schiff R 2011 Mechanisms of endocrine resistance in breast cancer. Annual Review of Medicine 62 233-247. (https://doi. org/10.1146/annurev-med-070909-182917)

Osborne CK, Hamilton B, Titus G \& Livingston RB 1980 Epidermal growth factor stimulation of human breast cancer cells in culture. Cancer Research 40 2361-2366.

O'Shaughnessy J, Campone M, Brain E, Neven P, Hayes D, Bondarenko I, Griffin TW, Martin J, De Porre P, Kheoh T, et al. 2016 Abiraterone acetate, exemestane or the combination in postmenopausal patients with estrogen receptor-positive metastatic breast cancer. Annals of Oncology 27 106-113. (https://doi. org/10.1093/annonc/mdv487).

Pascall JC 1997 Post-transcriptional regulation of gene expression by androgens: recent observations from the epidermal growth factor gene. Journal of Molecular Endocrinology 18 177-180. (https://doi. org/10.1677/jme.0.0180177)

Peters AA, Buchanan G, Ricciarelli C, Bianco-Miotto T, Centenera MM, Harris JM, Jindal S, Segara D, Jia L, Moore NL, et al. 2009 Androgen receptor inhibits estrogen receptor-alpha activity and is prognostic in breast cancer. Cancer Research 69 6131-6140. (https://doi. org/10.1158/0008-5472.CAN-09-0452)

Peters AA, Ingman WV, Tilley WD \& Butler LM 2011 Differential effects of exogenous androgen and an androgen receptor antagonist in the peri- and postpubertal murine mammary gland. Endocrinology $\mathbf{1 5 2}$ 3728-3737. (https://doi.org/10.1210/en.2011-1133)

Prenzel N, Fischer OM, Streit S, Hart S \& Ullrich A 2001 The epidermal growth factor receptor family as a central element for cellular signal transduction and diversification. Endocrine-Related Cancer 8 11-31. (https://doi.org/10.1677/erc.0.0080011)

Proverbs-Singh T, Feldman JL, Morris MJ, Autio KA \& Traina TA 2015 Targeting the androgen receptor in prostate and breast cancer: several new agents in development. Endocrine-Related Cancer 22 R87-R106. (https://doi.org/10.1530/ERC-14-0543)

Rahim B \& O'Regan R 2017 AR signaling in breast cancer. Cancers 9 E21. (https://doi.org/10.3390/cancers9030021)

Rakha EA, El-Sayed ME, Green AR, Lee AH, Robertson JF \& Ellis IO 2007 Prognostic markers in triple-negative breast cancer. Cancer 109 25-32. (https://doi.org/10.1002/cncr.22381)

Recchione C, Venturelli E, Cavalleri A, Martinetti A \& Secreto G 1995 Testosterone, dihydrotestosterone and oestradiol levels in postmenopausal breast cancer tissues. Journal of Steroid Biochemistry and Molecular Biology 52 541-546. (https://doi.org/10.1016/09600760(95)00017-T)

Rechoum Y, Rovito D, Iacopetta D, Barone I, Andò S, Weigel NL, O'Malley BW, Brown PH \& Fuqua SA 2014 AR collaborates with ER $\alpha$ in aromatase inhibitor-resistant breast cancer. Breast Cancer Research and Treatment 147 473-485. (https://doi.org/10.1007/s10549-014-3082-8)

Reid SE, Murthy MS, Kaufman M \& Scanlon EF 1996 Endocrine and paracrine hormones in the promotion, progression and recurrence of breast cancer. British Journal of Surgery 83 1037-1046. (https://doi. org/10.1002/bjs.1800830805)

Ropka ME, Keim J \& Philbrick JT 2010 Patient decisions about breast cancer chemoprevention: a systematic review and metaanalysis. Journal of Clinical Oncology 28 3090-3095. (https://doi.org/10.1200/ JCO.2009.27.8077)
Rotterdam ESHRE/ASRM-Sponsored PCOS Consensus Workshop Group 2004 Revised 2003 consensus on diagnostic criteria and long-term health risks related to polycystic ovary syndrome (PCOS). Human Reproduction 19 41-47. (https://doi.org/10.1093/humrep/deh098)

Santen RJ, Brodie H, Simpson ER, Siiteri PK \& Brodie A 2009 History of aromatase: saga of an important biological mediator and therapeutic target. Endocrine Reviews 30 343-375. (https://doi.org/10.1210/ er.2008-0016)

Sasano H, Nagasaki S, Miki Y \& Suzuki T 2009a New developments in intracrinology of human breast cancer: estrogen sulfatase and sulfotransferase. Annals of the New York Academy of Sciences 1155 76-79. (https://doi.org/10.1111/j.1749-6632.2008.03683.x.)

Sasano H, Miki Y, Nagasaki S \& Suzuki T 2009b In situ estrogen production and its regulation in human breast carcinoma: from endocrinology to intracrinology. Pathology International 59 777-789. (https://doi.org/10.1111/j.1440-1827.2009.02444.x)

Schuerch C, Rosen PP, Hirota T, Itabashi M, Yamamoto H, Kinne DW \& Beattie EJ Jr 1982 A pathologic study of benign breast diseases in Tokyo and New York. Cancer 50 1899-1903. (https://doi.org/ 10.1002/1097-0142(19821101)50:9<1899::AID-CNCR282050 0942>3.0.CO;2-A)

Secreto G, Venturelli E, Meneghini E, Greco M, Ferraris C, Gion M, Zancan M, Fabricio AS, Berrino F, Cavalleri A, et al. 2009 Testosterone and biological characteristics of breast cancers in postmenopausal women. Cancer Epidemiology, Biomarkers and Prevention 18 2942-2948. (https://doi.org/10.1158/1055-9965.EPI09-0540)

Secreto G, Meneghini E, Venturelli E, Cogliati P, Agresti R, Ferraris C, Gion M, Zancan M, Fabricio AS, Berrino F, et al. 2011 Circulating sex hormones and tumor characteristics in postmenopausal breast cancer patients. A cross-sectional study. International Journal of Biological Markers 26 241-246. (https://doi.org/10.5301/ JBM.2011.8883)

Secreto G $2012 a$ The androgen-excess theory of breast cancer. In The Androgen-Excess Theory of Breast Cancer, pp 47-70. Eds G Secreto \& B Zumoff. Trivandrum: Research Signpost. (available at: http://www. trnres.com/ebook.php)

Secreto G $2012 b$ Endocrine classification of postmenopausal breast cancers. In The Androgen-Excess Theory of Breast Cancer, pp 80-109. Eds G Secreto \& B Zumoff. Trivandrum: Research Signpost. (available at: http://www.trnres.com/ebook.php)

Secreto G, Sieri S, Agnoli C, Grioni S, Muti P, Zumoff B, Sant M, Meneghini E \& Krogh V 2016 A novel approach to breast cancer prevention: reducing excessive ovarian androgen production in elderly women. Breast Cancer Research and Treatment 158 553-561. (https://doi.org/10.1007/s10549-016-3901-1)

Secreto G, Muti P, Sant M, Meneghini E \& Krogh V 2017 Medical ovariectomy in menopausal breast cancer patients with high testosterone levels: a further step toward tailored therapy. EndocrineRelated Cancer 24 C21-C29. (https://doi.org/10.1530/ERC-17-0251)

Selim AG \& Wells CA 1999 Immunohistochemical localisation of androgen receptor in apocrine metaplasia and apocrine adenosis of the breast: relation to oestrogen and progesterone receptors. Journal of Clinical Pathology 52 838-841. (https://doi.org/10.1136/ jcp.52.11.838)

Sheflin LG, Brooks EM, Keegan BP \& Spaulding SW 1996 Increased epidermal growth factor expression produced by testosterone in the submaxillary gland of female mice is accompanied by changes in poly-A tail length and periodicity. Endocrinology 137 2085-2092. (https://doi.org/10.1210/endo.137.5.8612551)

Shekhar MP, Pauley R \& Heppner G 2003 Host microenvironment in breast cancer development. Extracellular matrix-stromal cell contribution to neoplastic phenotype of epithelial cells in the breast. Breast Cancer Research 5 130-135. (https://doi.org/10.1186/bcr580)

Shen CC, Yang AC, Hung JH, Hu LY \& Tsai SJ 2015 A nationwide population-based retrospective cohort study of the risk of uterine, 
ovarian and breast cancer in women with polycystic ovary syndrome. Oncologist 20 45-49. (https://doi.org/10.1634/ theoncologist.2014-0311)

Shibuya R, Suzuki T, Miki Y, Yoshida K, Moriya T, Ono K, Akahira JI, Ishida T, Hirakawa H, Evans DB, et al. 2008 Intratumoral concentration of sex steroids and expression of sex steroid producing enzymes in ductal carcinoma in situ of human breast. EndocrineRelated Cancer 15 113-124. (https://doi.org/10.1677/ERC-07-0092)

Sikora MJ, Cordero KE, Larios JM, Johnson MD, Lippman ME \& Rae JM 2009 The androgen metabolite 5alpha-androstane-3beta,17beta-diol (3betaAdiol) induces breast cancer growth via estrogen receptor: implications for aromatase inhibitor resistance. Breast Cancer Research and Treatment 115 289-296. (https://doi.org/10.1007/ s10549-008-0080-8)

Sluijmer AV, Heineman MJ, Koudstaal J, Theunissen PH, de Jong FH \& Evers JL 1998 Relationship between ovarian production of estrone, estradiol, testosterone, and androstenedione and the ovarian degree of stromal hyperplasia in postmenopausal women. Menopause 5 207210. (https://doi.org/10.1097/00042192-199805040-00004)

Sommers SC \& Teloh HA 1952 Ovarian stromal hyperplasia in breast cancer. AMA Archives of Pathology 53 160-166.

Speiser PW, Dupont B, Rubinstein P, Piazza A, Kastelan A \& New MI 1985 High frequency of nonclassical steroid 21-hydroxylase deficiency. American Journal of Human Genetics 37 650-667.

Suzuki T, Nakata T, Miki Y, Kaneko C, Moriya T, Ishida T, Akinaga S, Hirakawa H, Kimura M \& Sasano H 2003 Estrogen sulfotransferase and steroid sulfatase in human breast carcinoma. Cancer Research 63 2762-2770. (http://cancerres.aacrjournals.org/content/63/11/2762)

Suzuki T, Miki Y, Moriya T, Akahira J, Ishida T, Hirakawa H, Yamaguchi Y, Hayashi S \& Sasano H 2006 5alpha-reductase type 1 and aromatase in breast carcinoma as regulators of in situ androgen production. International Journal of Cancer 120 285-291. (https://doi org/10.1002/ijc.22317)

Suzuki T, Miki Y, Akahira J, Moriya T, Ohuchi N \& Sasano H 2008 Aromatase in human breast carcinoma as a key regulator of intratumural sex steroid concentrations. Endocrine Journal $\mathbf{5 5}$ 455-463. (https://doi.org/10.1507/endocrj.K07E-053)

Suzuki T, Miki Y, Takagi K, Hirakawa H, Moriya T, Ohuchi N \& Sasano H 2010 Androgens in human breast carcinoma. Medical Molecular Morphology 43 75-81. (https://doi.org/10.1007/s00795-010-0494-3)

Swerdloff RS, Dudley RE, Page ST, Wang C \& Salameh WA 2017 Dihydrotestosterone: biochemistry, physiology, and clinical implications of elevated blood levels. Endocrine Reviews 38220 - 254 . (https://doi.org/10.1210/er.2016-1067)

Talley RW, Haines CR, Waters MN, Goldenberg IS, Olson KB \& Bisel HF 1973 A dose-response evaluation of androgens in the treatment of metastatic breast cancer. Cancer 32 315-320. (https://doi. org/10.1002/1097-0142(197308)32:2<315::AIDCNCR2820320206>3.0.CO;2-Q)
Tzahar E, Waterman H, Chen X, Levkowitz G, Karunagaran D, Lavi S, Ratzkin BJ \& Yarden Y 1996 A hierarchical network of interreceptor interactions determines signal transduction by Neu differentiation factor/neuregulin and epidermal growth factor. Molecular and Cellular Biology 16 5276-5287. (https://doi.org/10.1128/MCB.16.10.5276)

Van Landeghem AA, Poortman J, Nabuurs M \& Thijssen JHH 1985 Endogenous concentration and subcellular distribution of estrogens in normal and malignant human breast tissue. Cancer Research $\mathbf{4 5}$ 2900-2906.

Vera-Badillo FE, Templeton AJ, de Gouveia P, Diaz-Padilla I, Bedard PL, Al-Mubarak M, Seruga B, Tannock IF, Ocana A \& Amir E 2014 Androgen receptor expression and outcomes in early breast cancer: a systematic review and meta-analysis. Journal of the National Cancer Institute 106 djt319. (https://doi.org/10.1093/jnci/djt319)

Vermeulen A, Deslypere JP, Paridaens R, Leclercq G, Roy F \& Heuson JC 1986 Aromatase, 17 $\beta$-hydroxysteroid dehydrogenase and intratissular sex hormone concentrations in cancerous and normal glandular breast tissue in postmenopausal women. European Journal of Cancer and Clinical Oncology 22 515-525. (https://doi.org/10.1016/02775379(86)90121-5)

Visscher DW, Frank RD, Carter JM, Vierkant RA, Winham SJ, Heinzen EP, Broderick BT, Denison LA, Allers TM, Johnson JL, et al. 2017 Breast cancer risk and progressive histology in serial benign biopsies. Journal of the National Cancer Institute 109 djx035. (https:// doi.org/10.1093/jnci/djx035)

Vranic S, Tawfik O, Palazzo J, Bilalovic N, Eyzaguirre E, Lee LM, Adegboyega P, Hagenkord J \& Gatalica Z 2010 EGFR and HER-2/neu expression in invasive apocrine carcinoma of the breast. Modern Pathology 23 644-653. (https://doi.org/10.1038/modpathol.2010.50)

Wales NAM \& Ebling FJ 1971 The control of the apocrine glands of the rabbit by steroid hormones. Journal of Endocrinology 51 763-770. (https://doi.org/10.1677/joe.0.0510763)

Waters EA, Cronin KA, Graubard BI, Han PK \& Freedman AN 2010 Prevalence of tamoxifen use for breast cancer chemoprevention among U.S. women. Cancer Epidemiology, Biomarkers and Prevention 19 443-446. (https://doi.org/10.1158/1055-9965.EPI-09-0930)

Wells CA \& El-Ayat GA 2007 Non-operative breast pathology: apocrine lesions. Journal of Clinical Pathology 60 1313-1320. (https://doi. org/10.1136/jcp.2006.040626)

Wellings SR \& Alpers CE 1987 Apocrine cystic metaplasia: subgross pathology and prevalence in cancer-associated versus random autopsy breasts. Human Pathology 18 381-386. (https://doi. org/10.1016/S0046-8177(87)80169-7)

Wieduwilt MJ \& Moasser MM 2008 The epidermal growth factor receptor family: biology driving targeted therapeutics. Cellular and Molecular Life Science 65 1566-1584. (https://doi.org/10.1007/s00018-008-7440-8)

Yaghjyan L \& Colditz GA 2011 Estrogens in the breast tissue: a systematic review. Cancer Causes and Control 22 529-540. (https:// doi.org/10.1007/s10552-011-9729-4)

Received in final form 27 October 2018

Accepted 5 November 2018

Accepted Preprint published online 7 November 2018 https://erc.bioscientifica.com

https://doi.org/10.1530/ERC-18-0429 (c) 2019 Society for Endocrinology Published by Bioscientifica Ltd. Printed in Great Britain 